International Journal of Biology, Pharmacy and Allied Sciences (IJBPAS)

'A B ridge Between Caboratory and QRende'

WwW.iibpas.com

\title{
INCIDENCE OF BK VIRUS INFECTION IN RENAL TRANSPLANT
}

\section{TRIVEDI VB ${ }^{a^{*}}$, CHAUDHARY AA ${ }^{\mathrm{b}}$, PANDYA KG ${ }^{\mathrm{a}}$, DALAI SK ${ }^{\mathrm{c}}$ AND TRIVEDI HL ${ }^{\mathrm{a}}$}

${ }^{a}$ Institute of Kidney Disease and Research Center, Ahmedabad, Gujarat, India

${ }^{\mathrm{b}}$ College of Medicine, Al-Imam Mohammad Ibn Saud Islamic University (IMSIU), Riyadh-13317-7544, Kingdom of Saudi Arabia (KSA)

${ }^{c}$ Faculty of Science, Institute of Science, Nirma University, Ahmedabad, Gujarat, India

*Corresponding author: Varsha Bhagavatprasad Trivedi: Institute of Kidney Disease and Research

Center, Ahmedabad, Gujarat, India; Email: varshabtrivedi@gmail.com

Received $19^{\text {th }}$ Sept. 2018; Revised $7^{\text {th }}$ Oct. 2018; Accepted $9^{\text {th }}$ Nov. 2018; Available online $1^{\text {st }}$ Feb. 2019

https://doi.org/10.31032/IJBPAS/2019/8.2.4641

ABSTRACT

$\mathrm{BK}$ virus (BKV) is a polyomavirus that associated nephritis (BKVAN) and a significant risk factor for renal transplant dysfunction and allograft survival. The pathogenesis of BKVAN needs to be further investigated and the virus functions as still unclear; nevertheless there are a variety of hypotheses that indicate, host factors play important roles. Higher prevalence of BK virus infection in recent years has been correlated with acute rejection rates and the use of potent immunosuppressive agents. Although over immunosuppression remains the primary risk factor for BK infection after transplantation, male gender, older recipient age and ureteral stent placement implicated as risk factors. The diagnosis of BKV is laboratory based method for its effects in urine, blood, and renal tissue. Some laboratory assay has provided new insights into the immune response to BK and may help guide therapy in the future. In the past, approximately 30 to $60 \%$ of patients with BK virus nephritis developed graft failure but early detection and routine screening has been shown to be effective in preventing allograft loss. In the study, we screened 1240 patients and out of these 106 (8.54\%) found positive for BKV. The rate of viruria and viremia were $69(65 \%)$ and $37(34.9 \%)$ out of 
total BKV positive. Their mean of serum creatinine level were $1.56 \pm 0.2 \mathrm{mg} / \mathrm{dl}$ and $2.39 \pm 0.3 \mathrm{mg} / \mathrm{dl}$ in viruria and viremia, respectively.

\section{Keywords: BK virus (BKV), Immunosuppression, Nephritis, Kidney Transplantation, Allograft Survival INTRODUCTION}

BK virus was isolated from the urine of a renal transplant recipient with ureteric stenosis in 1971 [1], since then, there have been numerous research on $\mathrm{BKV}$ infection in renal transplant recipients [2-6]. BKV is a double-stranded circular DNA virus belongs to the polyomavirus family, which encodes three capsid structural proteins. Based on DNA sequence variations, six different genotypes have been identified of $\mathrm{BKV}$. This virus enters in the body in childhood [7-8], but emergence has coincided with the use of new potent immunosuppressive medications [2, 9]. The incidence of BK virus and its pathogenesis has increased in recent years but factors that lead to it remain poorly understood. The ability of clinicians to recognize this infection and availability of better diagnostic tools may be contributing to higher prevalence of this disease in recent years [10].

$\mathrm{BKV}$ affects up to $8 \%$ of recipients, significant risk factor for renal transplant dysfunction and frequently results in allograft loss [11]. Hogan et al. [12] and Gardner et al. [13] found in their research that the seroprevalence for BKV was 80 to $88 \%$ pretransplantation. The post-transplantation rates of BK virus infection were 18 to $44 \%$. The first 3 months after transplantation BK virus infections found asymptomatic and infection associated with a rising creatinine with a tubulointerstitial nephritis that mimics rejection. Prevalence of BK virus within 1 year of post-transplantation is approximately $20 \%[12,14]$ and is higher than the prevalence of acute rejection of $13 \%$ [15]. The decrease in immunosuppression that is needed to treat infection is opposite to the increases that are needed to treat rejection. So increased immunosuppression needs to be avoided to prevent possible complications. The use of potent immunosuppressive therapy to play a role in the occurrence of this infection $[11,16]$. Donor and recipient characteristics may also play a role in the development of BKV.

\section{PATIENTS AND METHOD}

\section{Data Collection}

All related were collected as sex, date of birth, height, weight, blood group, etiology of end-stage renal disease (ESRD), the type and duration of pre-transplant renal replacement therapy, hepatitis B virus, hepatitis $\mathrm{C}$ virus (HCV), cytomegalovirus (CMV) status and the number of human leukocyte antigen (HLA) mismatches of all included patients the study. In 
addition, type of the induction treatment; the immunosuppressive drugs and their doses used and some biochemical data also were recorded.

\section{Samples Collection and Amplification}

This is a prospectively single center study, conducted in Institute of Kidney Disease and Research Center, Ahmadabad, Gujarat, India in 2013-2017. In this study, 1240 renal allograft recipients were studied to identify risk factors for BKV replication. During quarterly visits, we were measured urine for BKV DNA in the blood and urine sample of patients after transplantation. Samples of blood and urine were collected for the measurement of BKV DNA. The fresh blood and urine sample or 24 hours stored sample were used for DNA isolation. DNAs were extracted using commercial columns based DNA isolation kit (QIAamp Circulating Nucleic Acid Kit, Qiagen, U.S.A.). After the nucleic acid was obtained, BKV presence and quantification were measured with a Applied Biosystems ${ }^{\mathrm{TM}} 7500$ real time PCR instrument (Thermo Fisher) by using a specific BKV kits. BKV quantitative PCR assay kits were obtain from invitrogen (Thermo Fisher) based on TaqMan ${ }^{\circledR}$ probe and assay were designed according to the manufacturer's instructions.

\section{RESULTS}

After transplantation, we found 106 $(8.54 \%)$ patients positive for BK virus out of 1240 screened patients. Throughout the entire follow-up period (2013-2017), the rates of viruia in $69(65 \%)$ patients (57 male and 12 female) and viremia in $37(34.9 \%)$ patients (34 male and 3 female) out of 106 positive for $\mathrm{BKV}$, their mean serum creatinine level were $1.56 \pm 0.2 \mathrm{mg} / \mathrm{dl}$ and $2.39 \pm 0.3 \mathrm{mg} / \mathrm{dl}$ in viruria and viremia, respectively. We have lost followup of 25 patients and most of them were from viruria group $16(2 \mathrm{BK}+14 \mathrm{AMR})$ whereas in viremia group 9 (3 BK $+6 \mathrm{AMR})$. Out of positive for BK, nine patients lost allograft and three lost their life (Table 1).

Most recipients received living donors, majority of parents, siblings, spouses and other relatives. In VIREMIA group the maximum number of HLA match was 10 in 5 patients. While minimum HLA match was 1 in 7 patients. The maximum graft lost 4 , found in 5 HLA match group out of 37 patients (Table 2). In VIRURIA group the maximum number of HLA match 19 in 5 patients and 1 in 8 patients. We found 5 allograft loss in this group, maximum 3 allograft loss were in 24 match and maximum 16 lost follow-up. Serum creatinine raise maximum in 19 and 24 HLA match (Table 3). 
Table 1: The number of patients with viruria 69 and viremia 37 out of the total 106 positive patients for BKV. During the period of 2016-2017

\begin{tabular}{|c|c|c|}
\hline GROUP= Total 106 Patients & VIRURIA=69 Patients & VIREMIA = 37 Patients \\
\hline SEX & $57 \mathrm{M}+12 \mathrm{~F}$ & $34 \mathrm{M} / 3 \mathrm{~F}$ \\
\hline MEAN S . Creatinine & $1.56 \pm 0.2 \mathrm{mg} / \mathrm{dl}$ & $2.39 \pm 0.3 \mathrm{mg}$ dl \\
\hline $\begin{array}{c}\text { Average BKV Positive } \\
\text { to Negative period }\end{array}$ & 274 Days & 112 Days \\
\hline Lost Follow-up & $16[2 \mathrm{BK}+14 \mathrm{AMR}]$ & $9[3 \mathrm{BK}+6 \mathrm{AMR}]$ \\
\hline Allograft Loss & 5 & 4 \\
\hline Patients Loss & 1 & 2 \\
\hline
\end{tabular}

Table 2: The table shows HLA match group in viremia patients. Amongst 37 viremia positive patients maximum graft lost found 4.

\begin{tabular}{|c|c|c|c|c|c|c|c|c|c|c|}
\hline $\begin{array}{c}\text { GROUP-1 VIREMIA } \\
=37 \text { Patients } \\
\text { HLA MATCH A, B, } \\
\text { Cw, DR, DQ } \\
\end{array}$ & PT's & $\begin{array}{c}\text { LOST } \\
\text { FOLLOW }\end{array}$ & $\begin{array}{l}\text { Allograft } \\
\text { LOSS }\end{array}$ & $\begin{array}{c}\text { Raise S. } \\
\text { Creatinine }\end{array}$ & $\begin{array}{c}\text { REJ. } \\
\text { Graft Biopsy }\end{array}$ & 2013 & 2014 & 2015 & 2016 & 2017 \\
\hline 0 & 6 & & & 3 & 1 AMR & & & & & \\
\hline 1 & 4 & & & 2 & 2 AMR & & & & & \\
\hline 2 & 5 & 1 & 1 & 1 & $1 \mathrm{BK}[\exp ]$ & & & 1 & 1 & \\
\hline 3 & 5 & 2 & & 3 & & 1 & 1 & & & \\
\hline 4 & 4 & 2 & 1 & 4 & & & 1 & & 1 & 1 \\
\hline 5 & 10 & 4 & 2 & 3 & $\begin{array}{c}2 \text { BK }+3 \text { AMR } \\
{[1 \text { exp }]}\end{array}$ & & 1 & 4 & 1 & 1 \\
\hline 6 & 2 & & & 2 & & & & & & \\
\hline 7 & 1 & & & 0 & & & & & & \\
\hline
\end{tabular}

Table 3: The table shows HLA matching in viruria patients. Amongst 69 viruria positive patients maximum graft lost found in 5

\begin{tabular}{|c|c|c|c|c|c|c|c|c|c|c|}
\hline $\begin{array}{c}\text { GROUP-2 VIRURIA } \\
\begin{array}{c}\text { 69 Patients } \\
\text { HLA MATCH A, B, } \\
\text { Cw, DR, DQ }\end{array}\end{array}$ & PT's & $\begin{array}{c}\text { LOST } \\
\text { FOLLOW }\end{array}$ & $\begin{array}{c}\text { Allograft } \\
\text { LOSS }\end{array}$ & $\begin{array}{c}\text { Raise S. } \\
\text { creatinine }\end{array}$ & $\begin{array}{c}\text { REJ. } \\
\text { Graft } \\
\text { Biopsy }\end{array}$ & 2013 & 2014 & 2015 & 2016 & 2017 \\
\hline $\mathbf{0}$ & 24 & 4 & 3 & 7 & 2 AMR & 2 & $1+1$ & $1+1$ & $3+1$ & \\
\hline 1 & 2 & 1 & & 1 & & & & & 1 & \\
\hline 2 & 8 & 1 & & 2 & 2 AMR & & & 1 & & \\
\hline 3 & 6 & 2 & 1 & 3 & 3 AMR & 1 & 1 & 1 & & \\
\hline 4 & 5 & 2 & 1 & 2 & 2 AMR & & & 1 & 1 & 1 \\
\hline 5 & 19 & 3 & & 6 & $\begin{array}{c}\text { BK+ 8 } \\
\text { AMR }\end{array}$ & 2 & 1 & & & \\
\hline 6 & 2 & 2 & & 1 & 1 AMR & & 1 & 1 & & \\
\hline 7 & 2 & 1 & & & & & & 1 & & \\
\hline 8 & 1 & & & & & & & & & \\
\hline
\end{tabular}

\section{DISCUSSION}

The prevalence of BK virus infection have been reported in some studies. It has been reported that the degree of immunosuppression is the most important risk factor for $\mathrm{BKV}$ infection. BK infection is a relatively common and early post-transplant complication after kidney transplantation. PCR in urine may be the first finding indicative of BKV infection and screening determined a significant and persistent viral load in urine. Viruria and viremia could be an advantage for early detection of reactivation and allow adjustment of immunosuppression. Viruria and viremia is 
more strongly associated with the development nephropathy. Prospective studies a with longer follow-up are still needed to evaluate different treatment strategies while assessing the possibility of chronic allograft dysfunction due to systematic reduction of immunosuppression.

In one study, reported that BKV replication is a reliable indicator of excessive immunosuppression. The prevalence of $\mathrm{BK}$ virus infection in kidney transplantation was $6.4 \%$ and $12.8 \%$ one month after transplantation, and $38.5 \%$ after four months of transplantation [17]. In another study, the prevalence of $\mathrm{BK}$ and $\mathrm{JC}$ virus infection in kidney transplant recipients was $30.5 \%, 17.6 \%$, and $3.9 \%$, respectively; most of them had BK virus [10]. The prevalence of $\mathrm{BK}$ virus infection was $7.4 \%$ in USA, assessed by serum DNA PCR and urine decoy cell [11]. In some study reported that, the prevalence of urine decoy cell, viruria, and viremia was $25 \%, 61.7 \%$, and $42.5 \%$, respectively [12].

In our study, viruria and viremia were associated with acute rejection. We also found that viremia was higher in patients with a short post-transplant period. The high rates of viruria and viremia for deceased donor transplantation might be related to the intensive use of immunosuppressive drugs, as indicated in some other studies. Viruria was first shown in 1971 in a renal recipient and found to be related to
BKVN [1]. Munoz et al found the frequency of viruria among renal recipients to be $26.5 \%$ in a prospective study of 156 heart, liver, or kidney transplantation patients [18]. One study found the frequency of viruria to be $13.6 \%$ in renal recipients out of 118 liver or kidney transplant [19]. In a prospective randomized trial the frequency of viruria was found to be $35 \%$ in a series of 200 renal transplantation patients in the first year [20]. Patients with longer posttransplantation times might be contribute to the lower overall incidence. However, it should be noted that even after second post-transplantation year, we detected patients with viruria. The frequency of BKV infection was lower in our transplant unit compared to previous reports. Reduced doses of immunosuppression seem to be the main factor that may explain the reduced frequency. However, an active screening strategy is still of importance for this patient group.

In conclusion, we obtained some important data about BKV infection, which is becoming a serious problem in transplant centers. Our study was conducted in a transplant center that performs mainly living donor transplantations, which is a different population than those described in previous works. We believe that this information will be valuable in the diagnosis and follow-up of BKV infection.

CONCLUTION 
We obtained some important data about BKV infection, that early diagnosis of viruria and viremia, immunosuppression reduction and use of antiviral therapy or the combination of both are BKV nephropathy treatment and management options.

\section{CONFLIT OF INTEREST}

The authors declare no conflict of interest for research and publication of this article.

\section{REFERENCES}

[1] Gardner SD, Field AM, Coleman DV, et al. New human papovavirus (BK) isolated from urine after renal transplantation. Lancet 1971; 1: 12531257.

[2] Purighalla R, ShapiroR, Mc Cauley J, Randhawa P. BK virus infection in a kidney allograft diagnosed by needle biopsy. Am. J Kidney Dis. 1995; 26(4): 671-673.

[3] Randhawa PS, Finkelsteing S, Scantelbury V, Shapiro R, Vivas C, Jordan M, Picken MM, Demetris AJ. Human polyoma virus-associated interstitial nephritis in the allograft kidney. Transplantation 1999; 67: 103109.

[4] Tremolada S, Akan S, Otte J, Khalili K, Ferrante P, Chaudhury PR, Woodle ES, Trofe-Clark J, White MK, Gordon J. Rare subtypes of BK virus are viable and frequently detected in renal transplant recipients with $\mathrm{BK}$ virusassociated nephropathy. Virology 2010; $404: 312-318$.

[5] Takasaka T, Goya N, Tokumoto T, Tanabe K, Toma H, Ogawa $\mathrm{Y}$, Hokama S, Momose A, Funyu T, Fujioka T, Omori S, Akiyama H, Chen Q, Zheng HY, Ohta N, Kitamura T, Yogo Y. Subtypes of BK virus prevalent in Japan and variation in their transcriptional control region. J Gen Virol 2004; 85: 2821-2827.

[6] Zhong S, Randhawa PS, Ikegaya H, Chen Q, Zheng HY, Suzuki M, Takeuchi T, Shibuya A, Kitamura T, Yogo Y. Distribution patterns of BK polyomavirus (BKV) subtypes and subgroups in American, European, and Asian populations suggest comigration of BKV and the human race. J Gen Virol 2009; 90:144-152.

[7] Stolt A, Sasnauskas K, Koskela P, Lehtinen M, Dillner J. Seroepidemiology of the human polyomaviruses. J Gen Virol 2003; 84:1499-1504.

[8] White LH, Casian A, Hilton R, Macphee IA, Marsh J, Sweny P, Trevitt R, Frankel AH, Warrens AN. BK virus nephropathy in renal 
transplant patients in London. Transplantation 2008; 85:1008-15.

[9] Binet I, Nickeleit V, Hirsch HH, Prince O, Dalquen P, Gudat F, Mihatsch MJ, Thiel G: Polyomavirus disease under new immunosuppressive drugs: A cause of renal graft dysfunction and graft loss. Transplantation 1999; 67: 918-922.

[10] Hariharan S. BK virus nephritis after renal transplantation. Kidney Int 2006; 69: $655-662$.

[11] Hirsch HH, Knowles W, Dickenmann M, Passweg J, Klimkait T, Mihatsch MJ, Steiger J. Prospective study of polyomavirus type BK replication and nephropathy in renal-transplant recipients. N Engl J Med 2002; 347: 488- 496.

[12] Hogan TF, Borden EC, McBain JA, Padgett BL, Walker DL. Human polyomavirus infections with JC virus and $\mathrm{BK}$ virus in renal transplant patients. Ann Intern Med 1980; 92: 373-378.

[13] Gardner SD, MacKenzie EF, Smith C, Porter AA. Prospective study of the human polyomaviruses BK and JC and cytomegalovirus in renal transplant recipients. J Clin Pathol 1998; 37: 578 586.
[14] Paracchini V, Garte S, Pedotti P, Poli F, Frison S, Taioli E. Molecular identification of simian virus 40 infection in healthy Italian subjects by birth cohort. Mol Med 2005; 11: 4851.

[15] Meier-Kriesche HU, Li S, Gruessner RW, Fung JJ, Bustami RT, Barr ML, Leichtman AB. Immunosuppression: Evolution in practice and trends, 19942004. Am J Transplant 2006; 6: 11111131.

[16] Prosser S, Hariharan S. Pathogenesis of BK virus infection after renal transplantation. Exp Rev Clin Immunol 2006; 2: 833-837.

[17] Hirsch HH, Brennan DC, Drachenberg $\mathrm{CB}$, Ginevri F, Gordon J, Limaye AP, Mihatsch MJ, Nickeleit V, Ramos E, Randhawa P, Shapiro R, Steiger J, Suthanthiran M, Trofe J. Polyomavirus-associated nephropathy in renal transplantation: interdisciplinary analyses and recommendations. Transplantation 2005; 79: 1277-86.

[18] Munoz P, Fogeda M, Bousa E, Verde E, Palomo J, Bañares R. Prevalence of BK virus replication among recipients of solid organ transplants. Clin Infect Dis, 2005; 41: 172-1725. 
[19] Splendiani, G, Cipriani, S, Condo, S.

Polyoma virus $\mathrm{BK}$ and renal dysfunction in a transplanted population. Transplant Proc 2004; 36(3): 713-715.

[20] Brennan, DC, Agha, I, Bohl, DL. Incidence of $\mathrm{BK}$ with tacrolimus versus cyclosporine and impact of preemptive immunosuppression reduction. Am J Transplant 2005; 5(3): 582-594. 